\title{
Case Study of a Solar Chimney in Mansoura, Egypt
}

\author{
M.S. Anter, Ahmed Ramzy and Ahmed M. Hamed
}

Mechanical Power Engineering Department, Faculty of Engineering, Mansoura University, Egypt

\begin{abstract}
A solar chimney system was established in Mansoura University which was designed as a square collector with an area of $100 \mathrm{~m}^{2}$, the side length $10 \mathrm{~m}$, height $8 \mathrm{~m}$ and the diameter $0.3 \mathrm{~m}$. It's floor was painted with black bitumen and covered with plastic having a thickness of 150 microns. The height of air inlet collector (periphery) was $0.15 \mathrm{~m}$ to investigate the effect of environmental temperature on the performance of solar chimney (SCS). Tests were carried out at a wide range of ambient temperatures and solar radiation. In this study, conducted on September 20 and 21, ambient temperature, air inlet temperature, the temperature under collector, the temperature under the chimney, air velocity and solar radiation during the two days were recorded with time. Experimental measurements indicate that as long as the collector air temperature increases, the velocity of air inside the chimney increases.
\end{abstract}

Keywords: Solar Energy, Solar chimney, Air Velocity, Updraft tower, Renewable energy.

\section{INTRODUCTION}

In recent years, rapid developments of the global economy and an increase in population and living standards have been posing great pressure on natural resources. Fossil fuels are, therefore, being exhausted at a fast rate. The utilization of fossil fuels has induced considerable climate change in warming the atmosphere by releasing greenhouse gases. On the other hand, this kind of energy produces acid rains, toxic gases and environmental contaminations [1].

Electricity production using solar thermal energy is currently one of the main research areas in the field of renewable energies [2].

The solar chimney power plant (SCPP) offers interesting opportunities to use clean solar radiation to satisfy the increasing world energy demand. It is designed to produce electric power on a large-scale by first converting solar energy into thermal energy which is then converted into kinetic energy to drive the wind turbine for power generation [3].

Solar chimney power plant has three essential elements: solar air collector, chimney and wind turbines. Air is heated by solar radiation under a low circular transparent collector open at the periphery. In the center of the collector is a vertical chimney. As hot air rises along the chimney, cold air comes in from the outer perimeter. The energy contained in the updraft is converted into mechanical energy by wind turbines at the base of the tower, and into electrical energy by conventional generators.

*Address correspondence to this author at the Mechanical Power Engineering Department, Faculty of Engineering, Mansoura University, Egypt;

Tel: (+2)01224407750; E-mail: amhamed@mans.edu.eg
The technologies for the SCPP components are simple and reliable, accessible to the technologically less developed countries, which are sunny and often have conventional energy resources. Little maintenance and no combustible fuel and cooling water are needed for SCPPs.

A major problem of SCPP is its low conversion efficiency as determined by the thermal performance of the system. However, the conversion efficiency of SCPP increases with the SC height. For commercial power plants producing energy economically, not only is a large collector area necessary for collecting solar energy but also a high gigantic SC is required to obtain a large driving force and to produce a large volumetric flow to drive big turbines. Furthermore, higher conversion efficiency for large-scale SCPP will also lead to a certain reduction in the energy cost.

Although the efficiency of this technology is low, many studies were carried out to improve the efficiency such as the effect of the inclined angle on the output in a solar chimney power plant system [4]. The best slope gradient of slope solar induced convective flows power generation system [5].

The concept of solar chimney power technology was first conceived in 1931 by a German author, Hanns Gunther, and has been proven with the successful operation of a pilot plant constructed in Manzanares, Spain in the early 1980s by Professor Schlaich with the support of both the German government and a Spanish electric company [6].

The project works on the principle that in the collector, solar radiation is used to heat an absorber (ordinarily soil or water bags) on the ground, and then a large body of air, heated by the absorber, rises the chimney, due to the density difference of air between 
the chimney base and the surroundings, driving large turbines to generate electricity. The collector had a radius of 122 meters while the chimney was 194.6 meters tall with a diameter of 5.08 meters. The plant produced an upwind velocity of $15 \mathrm{~m} / \mathrm{s}$ under no- load conditions [7]. The highest power output reached 41 kW from July to September in 1982 [8].

Since then, more and more researchers have been strongly interested in and studied this solar power technology which has huge potential applications world-wide.

In 1983, the American scientist Krisst built a courtyard solar chimney power setup with a power output of $10 \mathrm{~W}$. Its collector had a diameter of 6 meters while the chimney was 10 meters tall [9]. In 1997, three different power demonstration models of the solar chimney were built on the campus of the University of Florida, and both theoretical and experimental research on their performance was done [10]. Bernardes et al. presented a thermal and technical analysis by computer-aided calculation [11]. In 2000, Von Backström and Gannon developed a one-dimensional compressible flow approach to calculate all the thermodynamic variables depending on chimney height, wall friction additional losses, internal drag and area change [12]. In 2003, they also investigated the performance of a solar chimney turbine [13]. In 2005, Schlaich described the design of a commercial solar updraft chimney power system, presenting theory, practical experience, and economic analysis of solar updraft towers [14]. In 2005, A pilot experimental solar chimney power setup consisted of a $5 \mathrm{~m}$-radius air collector and an $8 \mathrm{~m}$-height chimney. The temperature distribution in the solar chimney power setup was measured. The temperature difference between the collector outlet and the ambient can usually reach $24.1^{\circ} \mathrm{C}$, which generates the driving force of airflow in the setup and the whole experimental setup power is 5 W, by Xinping Zhou, Jiakuan Yang, Bo Xiao1, Guoxiang Hou [15].

A program [16], to construct a solar chimney power plant with a power output of $100 \mathrm{MW}$ in a desert, in Rajasthan, India, was scheduled, but then was aborted owing to the potential danger of nuclear competition between India and Pakistan. Recently, the Australian government decided to support a proposed solar chimney power plant with a $1000 \mathrm{~m}$ chimney in Mildura, Australia, which can produce $200 \mathrm{MW}$ of electric power and was expected to be constructed in 2006 [17]. Combined solar chimney and PV system has been demonstrated and tested [18]. Two experimental models of a hybrid solar chimney were built and designed. The results demonstrated that the performance of the PV is improved due to cooling of PV surface by the chimney flowing air.

From the review of previos investigations, it can be concluded that new approaches to improve the solar chimney performance are highly welcome.

Practical experience and analysis of the performance parameters is still recommended for different ambient conditions. In the present study a solar chimney was designed and tested in the ambient conditions of Mansoura, Egypt. Local and low cost materials are used in the installation of the tested unit. The application of black coated roof surface is invesrigated in the present study. The performance parameters studied in the present investigation are the output power air speed. Moreover, the temperature at collector inle as wellas chimney inlet are demonstrated.

\section{THEORETICAL MODEL}

The presented simple model demonstrates the possibility of using the measured values of test parameters for data reduction and evaluate some performance unmeasured results.

\section{Solar Collector}

The energy balance equation of the chimney in the middle of the collector [19]

$Q=\dot{m} C_{p} \Delta T=(\tau \alpha) A_{\text {coll }} G-\beta \Delta T_{a} A_{\text {coll }}=\eta_{\text {coll }} A_{\text {coll }} G$

Where $\dot{m}$ denotes mass flow rate of hot air, flow through the solar chimney and can be calculated by the equation below

$\dot{\mathrm{m}}=\rho_{\text {coll }} \mathrm{A}_{\mathrm{c}} \mathrm{V}_{\mathrm{c}}$

the efficiency of the solar collector is given below

$\eta_{\text {coll }}=(\mathrm{T} \alpha)-\frac{\beta \Delta T a}{G}$

where $\Delta T_{a}$ is the difference between heat-absorbing layer and environment air temperature (the temperature of heat-absorbing layer was considered equal to the collector air temperature), $\rho$ is the air density at the outlet of solar collector, $\beta$ heat loss coefficient of solar collector (assumed to be $6 \mathrm{~W} / \mathrm{m}^{2} \mathrm{~K}$ ), $A_{c}$ is cross-sectional area of solar chimney, $A_{c o l l}$ is solar radiation field area, $G$ the solar radiation, $\mathrm{Ta}$ is 
absorption and permeability of material which solar collector is made of (assumed to be 0.64 ) and $\Delta \mathrm{T}$ is the difference between outlet of the collector and the ambient air temperature.

\section{Solar Chimney}

The chimney efficiency is expressed [19] as follows:

$\eta_{\mathrm{sc}}=\frac{P l o t}{Q}=\frac{g H s c}{C p T 0}$

where $\mathrm{H}_{\mathrm{sc}}$ is the height of the chimney, $\mathrm{P}_{\text {tot }}$ is the power contained in the flow, which can be written as,

$\mathrm{P}_{\text {tot }}=\eta_{\mathrm{sc}} Q=\frac{g H s c}{T 0} \rho_{\text {coll }} \mathrm{V}_{\mathrm{c}} \Delta \mathrm{T} \mathrm{A}_{\mathrm{c}}$

The pressure difference, $\Delta P_{\text {tot }}$, which is produced between the chimney base and the surroundings, is calculated by,

$\Delta \mathrm{P}_{\text {tot }}=\rho_{\text {coll }} \mathrm{g} \mathrm{H}_{\mathrm{sc}} \frac{\Delta T}{T 0}$

\section{Turbine}

Turbines are always placed at the base of the chimney. Turbines in a solar chimney work as a cased pressure-staged wind turbo generator in which, similar to a hydroelectric power station, static pressure is converted to rotational energy using a cased turbine.

Schlaich [20] recommended that the maximum mechanical power taken up by the turbine is:

$\mathrm{P}_{\mathrm{wt}, \max }=\frac{2}{3} \mathrm{~V}_{\mathrm{c}} \mathrm{A}_{\mathrm{c}} \Delta \mathrm{P}_{\text {tot }}=\frac{2}{3} \eta_{\text {coll }} \frac{g}{C p T 0} \mathrm{H}_{\mathrm{sc}} \mathrm{A}_{\text {coll }} \mathrm{G}$

If $P_{w t, m a x}$ is multiplied by $\eta_{w t}$ which contains both blade transmission and generator efficiency, this produces the electrical power from the solar chimney

$\mathrm{P}_{\mathrm{e}}=\frac{2}{3} \eta_{\text {coll }} \eta_{\mathrm{wt}} \frac{g}{C p T 0} \mathrm{H}_{\mathrm{sc}} \mathrm{A}_{\text {coll }} \mathrm{G}$

\section{SC System Description and Experimental Procedure}

A chimney, made from $0.001 \mathrm{~m}$ thick galvanized sheet of metal, $8 \mathrm{~m}$ high, $0.30 \mathrm{~m}$ in diameter, in the sun at all hours of the day and open areas, was manufactured in Mansoura University. A collector was made from $0.005 \mathrm{~m}$ thick, $0.04 \times 0.04 \mathrm{~m}$ square-shaped Iron Creteil with the top of the collector coated with 150 micron thick plastic. 5 thermometers having a range of $-40{ }^{\circ} \mathrm{C}$ to $70{ }^{\circ} \mathrm{C}$ with the measurement accuracy of \pm 0.1 were used to measure ambient temperature, air inlet temperature, collector temperature, air inlet

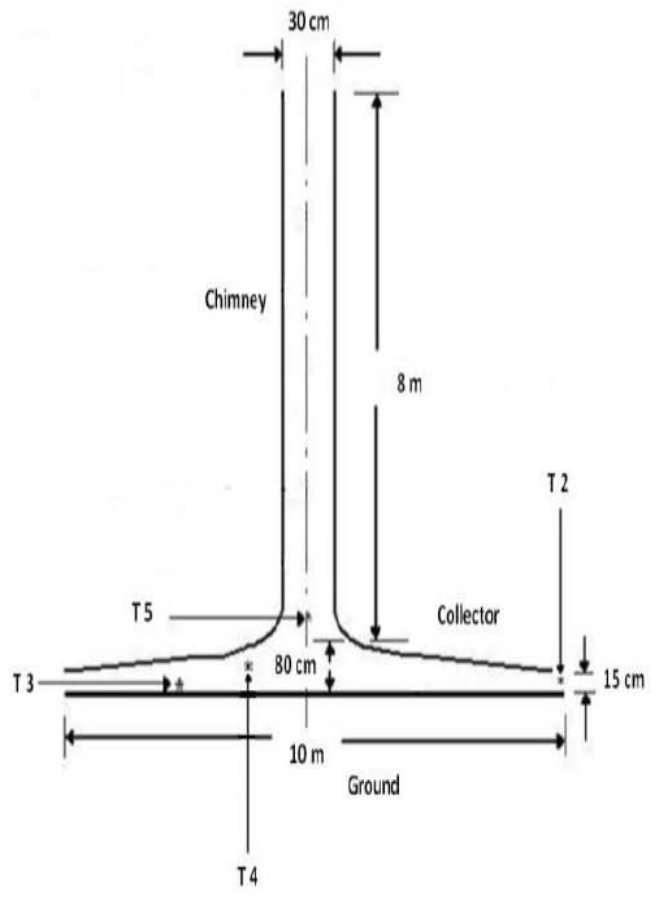

a

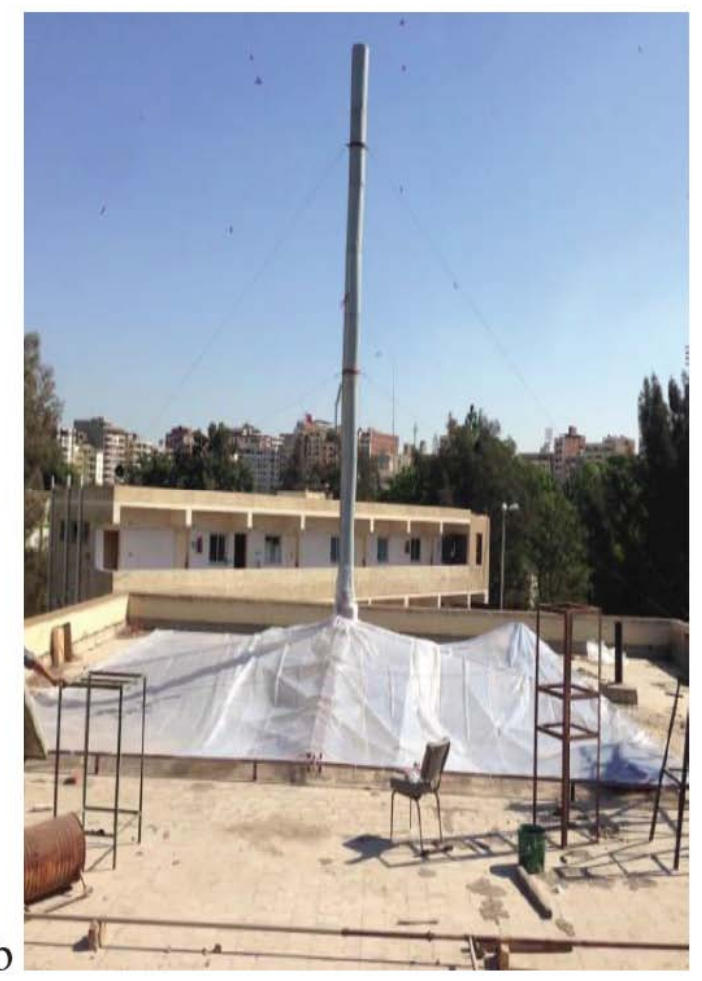

Figure 1: a. Schematic overview of the Solar Chimney principle. b. Picture of the system. 
chimney temperature, and chimney temperature. Anemometer, $\pm 0.1 \mathrm{~m} / \mathrm{s}$ accuracy, was used for measuring the air velocity in the chimney. TES data logging solar power meter wad used for measuring solar radiation. The main parameters of the solar chimney power setup is shown in Figure $\mathbf{1 a}$ and are listed in Table 1.

Table 1: Main Parameters of the Solar Chimney Power Plant

\begin{tabular}{|c|c|}
\hline Parameter & Value/m \\
\hline \hline Collector Area & $100 \mathrm{~m}^{2}$ \\
\hline Height from collector outlet to ground level & $0.8 \mathrm{~m}$ \\
\hline Periphery (Surrounding air inlet) & $0.15 \mathrm{~m}$ \\
\hline Chimney diameter & $0.3 \mathrm{~m}$ \\
\hline Chimney height & $8 \mathrm{~m}$ \\
\hline Effective transmittance and absorbance $(\mathrm{T \alpha})$ & 0.64 \\
\hline Cover heat loss coefficient $(\beta)$ & $6 \mathrm{~W} / \mathrm{m}^{2} \mathrm{~K}$ \\
\hline Ambient Temperature & $\mathrm{T} 1$ \\
\hline Inlet Temperature & $\mathrm{T} 2$ \\
\hline Collector Temperature & $\mathrm{T} 3$ \\
\hline Inlet Chimney Temperature & $\mathrm{T} 4$ \\
\hline Chimney Temperature & $\mathrm{T} 5$ \\
\hline
\end{tabular}

\section{Surrounding Air Inlet (Periphery) and Collector Description}

The collector is one of the most important parts in the solar chimney system. The collector was covered with a plastic thickness of 150 microns to produce hot air by the greenhouse effect. Figure 2 shows the construction steps (a to $\mathbf{f}$ ) of the collector of the solar tower system.

\section{Ground Description}

The special floor was prepared, where black bitumen paint covered the $100 \mathrm{~m}^{2}$ of surface as shown in Figure 3.

\section{Chimney Description}

The tower, which acts as a large chimney, is located at the center of the greenhouse. The chimney, made from $0.001 \mathrm{~m}$ thick galvanized sheet of metal is $8 \mathrm{~m}$ high, $0.30 \mathrm{~m}$ in diameter and fixed with six steel wires covered with plastic as shown in Figure 4.

\section{RESULTS AND DISCUSSION}

Measured values of solar radiation are plotted versus time as given in Figure 5. Values of radiation intensity around $800 \mathrm{Watt} / \mathrm{m}^{2}$ are recorded at midday. Different values of recorded temperatures are demonstrated in Figure $\mathbf{6}$. It is expected that the collector inlet temperature follows the ambient temperature Therefore, collector air inlet temperature increases depending on ambient temperature. Ambient temperature is an important factor affecting the performance of the solar chimney. The temperature of the the collector rapidly increases, consequently, the air velocity at the chimney increases as shown in Figure 7.

Air velocity in the chimney inlet is plotted versus collecter temperature as given in Figure 8. It is obvious that air velocity increases with collector temperature.
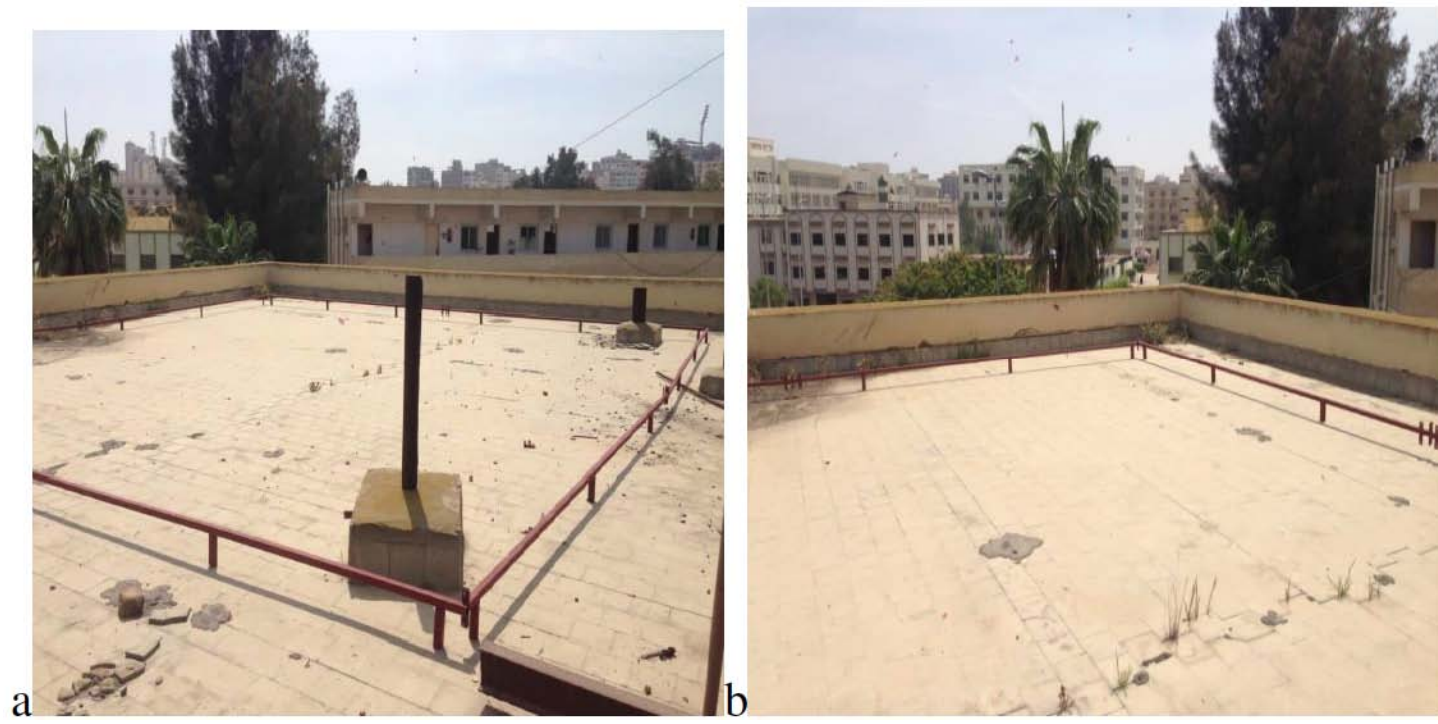

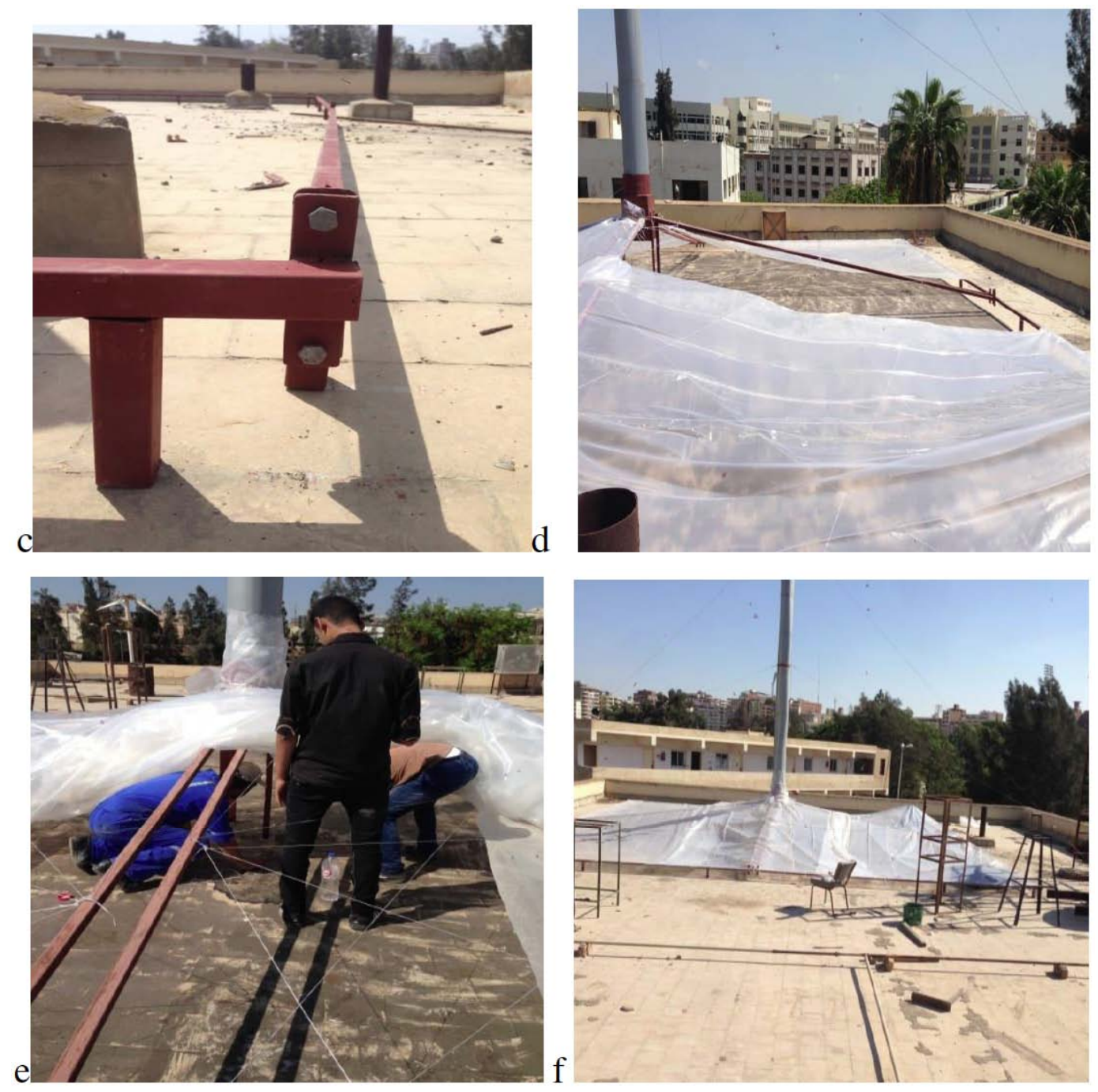

Figure 2: Pictures are showing the construction steps of the collector.

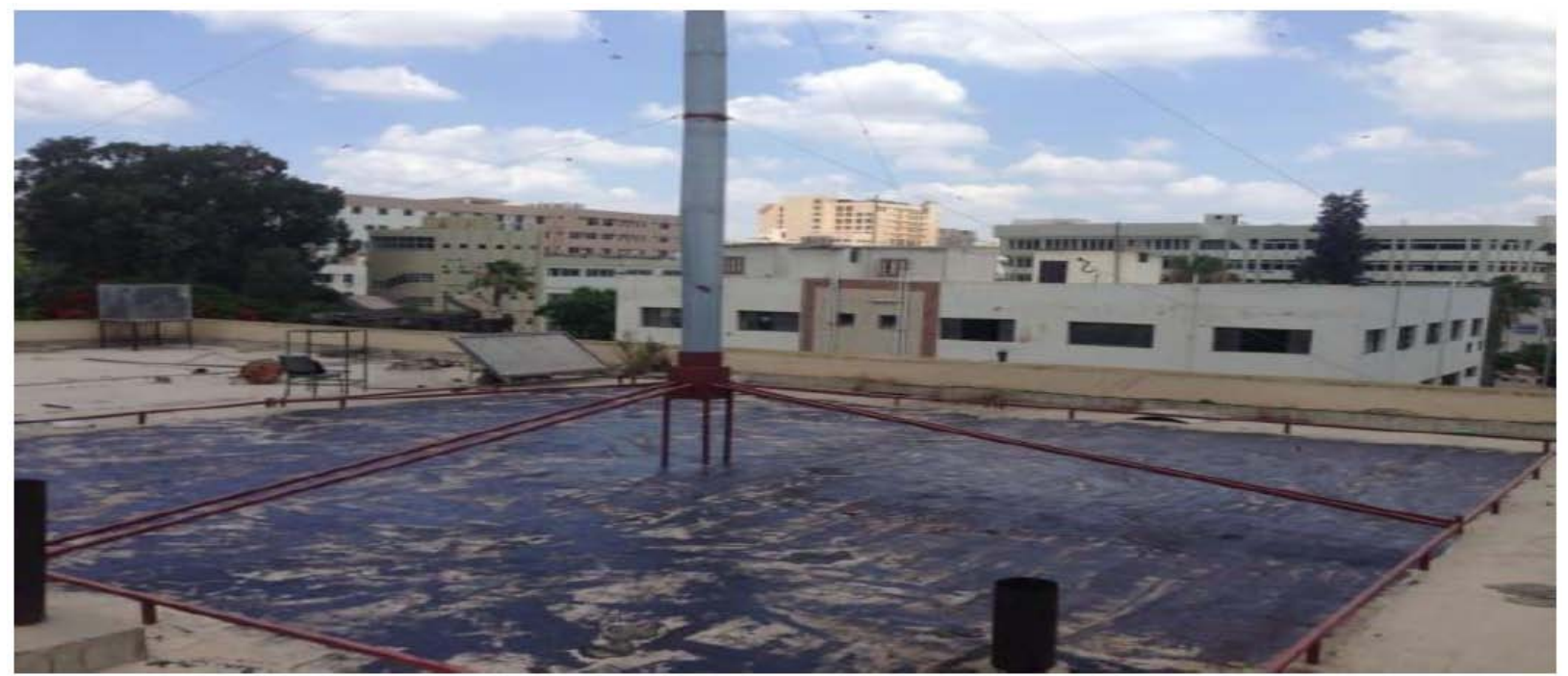

Figure 3: Pictures are showing the ground of solar tower system. 

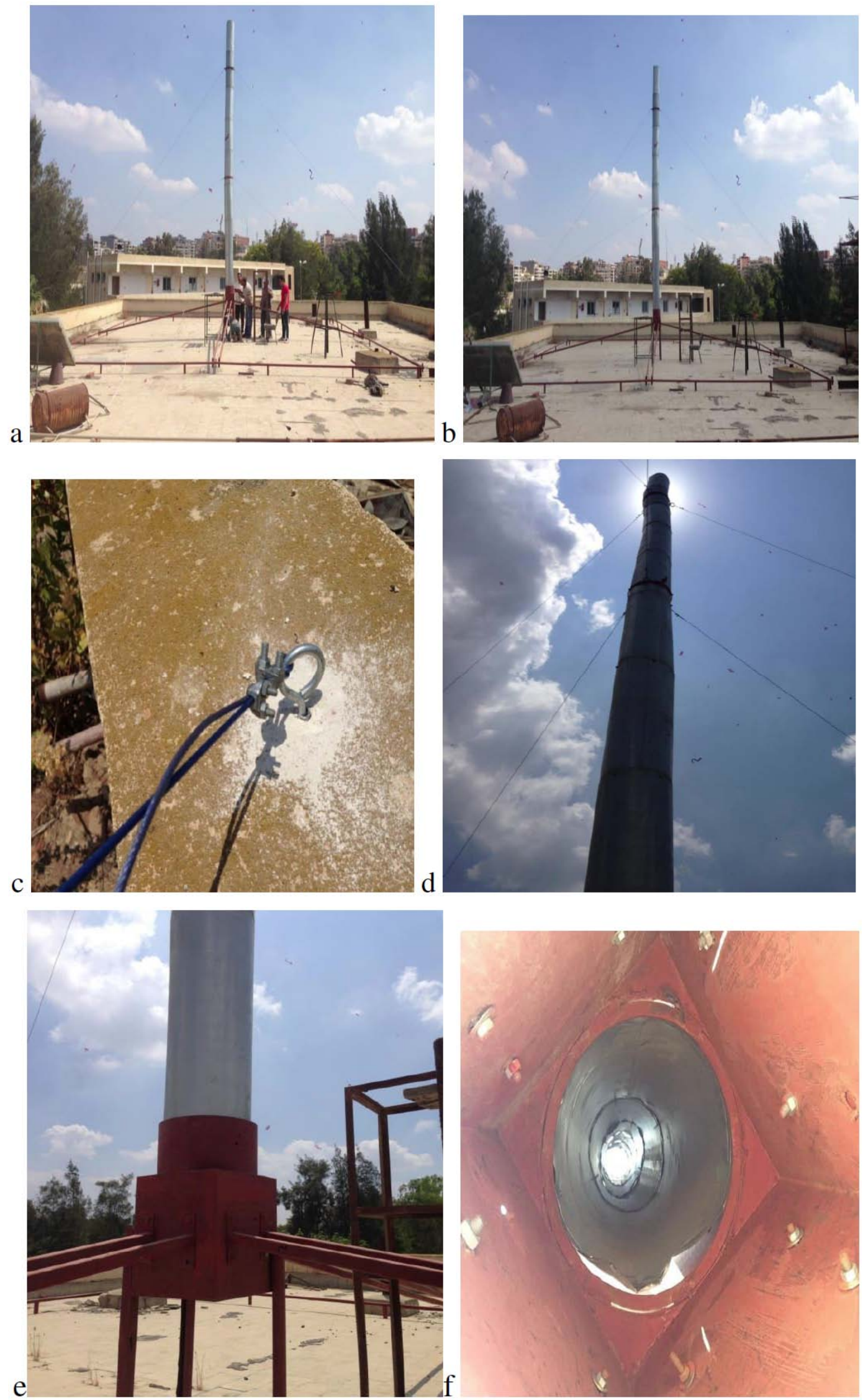

Figure 4: Pictures are showing the construction steps of the chimney. 


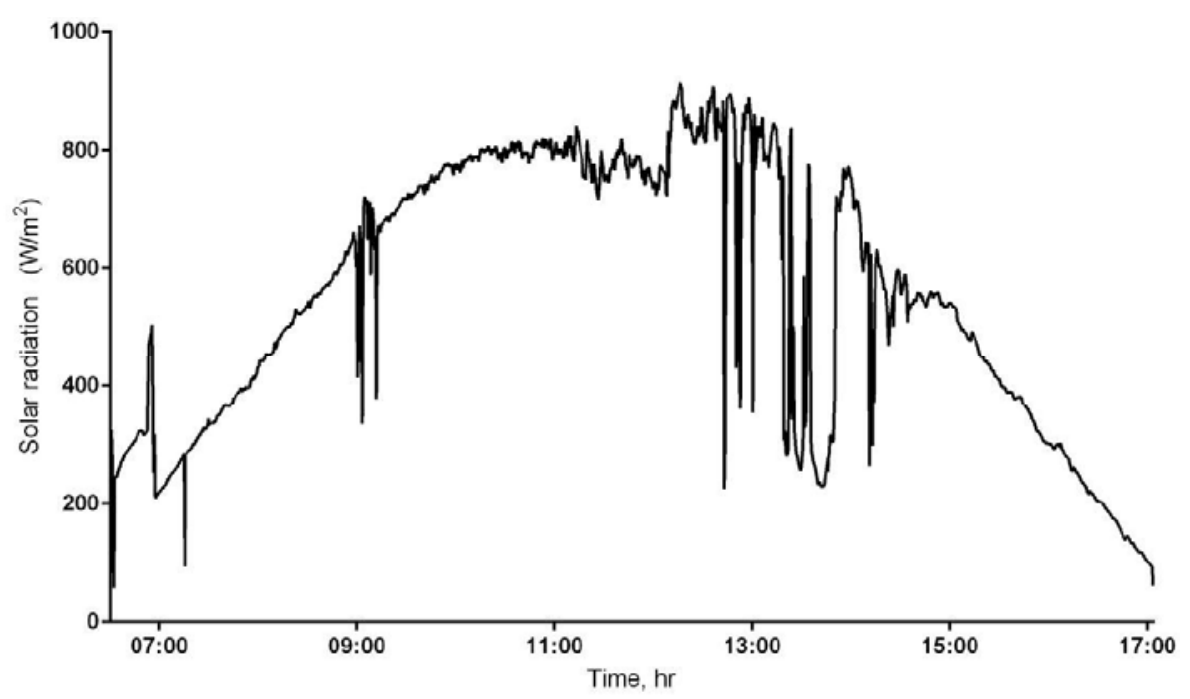

Figure 5: Daily variations in solar radiation.

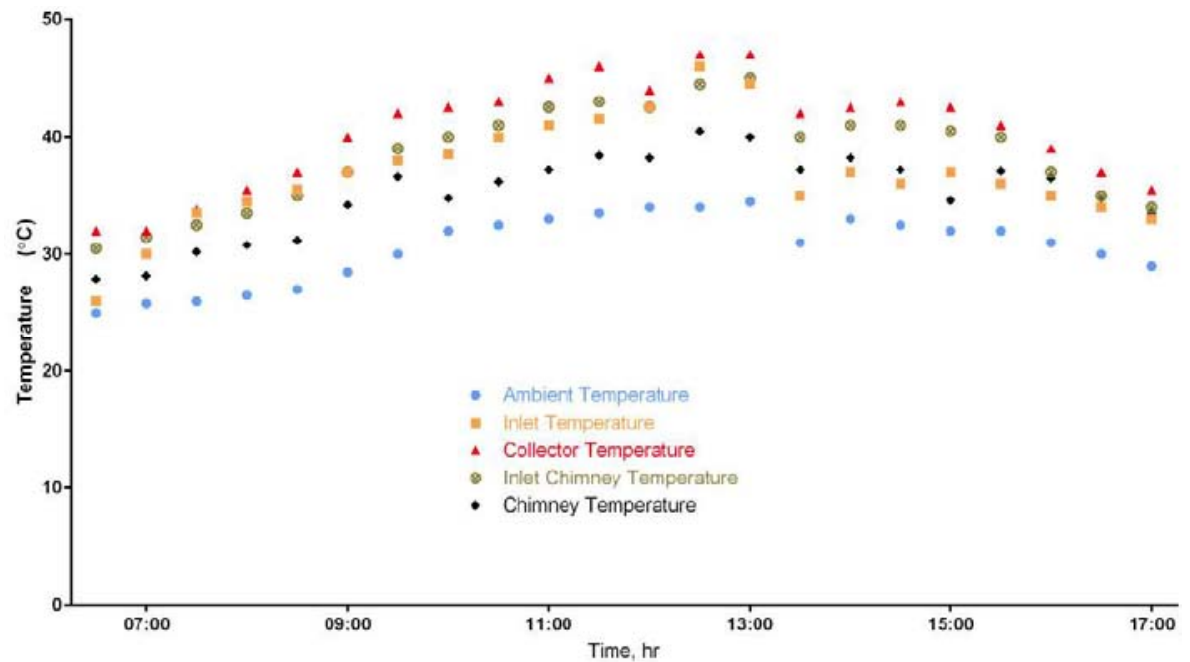

Figure 6: Daily variations of ambient temperature, inlet temperature, collector temperature, inlet chimney temperature and chimney temperature.

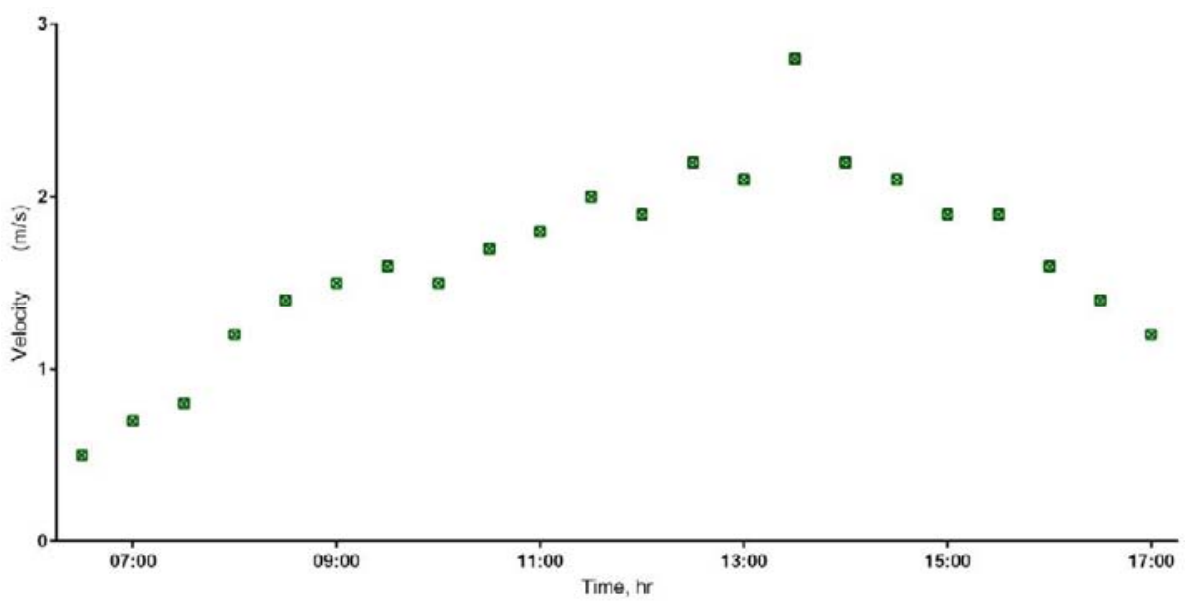

Figure 7: Daily variations of air velocity. 


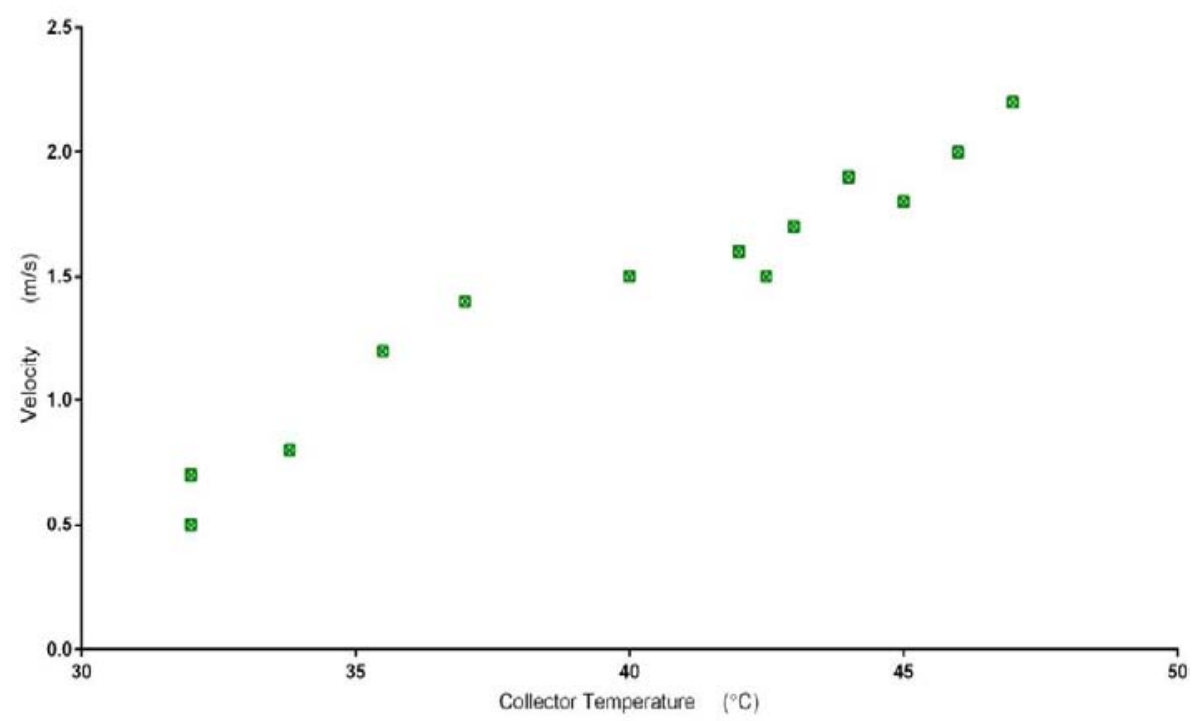

Figure 8: Effect of collector temperature on velocity.

An increase of collector temperature of about $15^{\circ} \mathrm{C}$ results in increase of air velocity from 0.5 to $2.0 \mathrm{~m} / \mathrm{s}$.

The ground was heated quickly with sunrise in the morning due to black paint absorption of radiation. The measurements were performed with half hour interval (started from $06.30 \mathrm{am}$ on the 20 and $21 \mathrm{st}$ of September until 05:00 pm). Along the following hours on each day, as the temperature was rapidly falling. Continuity of operation of solar chimney during the sunset period was provided by the stored heat in the roof surface as given in Figures from 9 to 11. In this study, the temperature difference between the collector outlet and the ambient reached $11-14{ }^{\circ} \mathrm{C}$ (see Figure
12), which generated the driving force of airflow in the setup with mechanical power reaches $7 \mathrm{~W}$.

Daily variation of measured and evaluated parameters (air velocity, heat gain, useful energy and power generated) are demonstrated as given in Figures from 13 to 17 for the next day of operation. The test results of the next day confirms the results for the day of operation. However, the generated power of he system is low as well as the overall efficiency. This may be due to the poor efficieny of the turbine, loss of heat from the collecting surface and low absorptivity of the paint used.

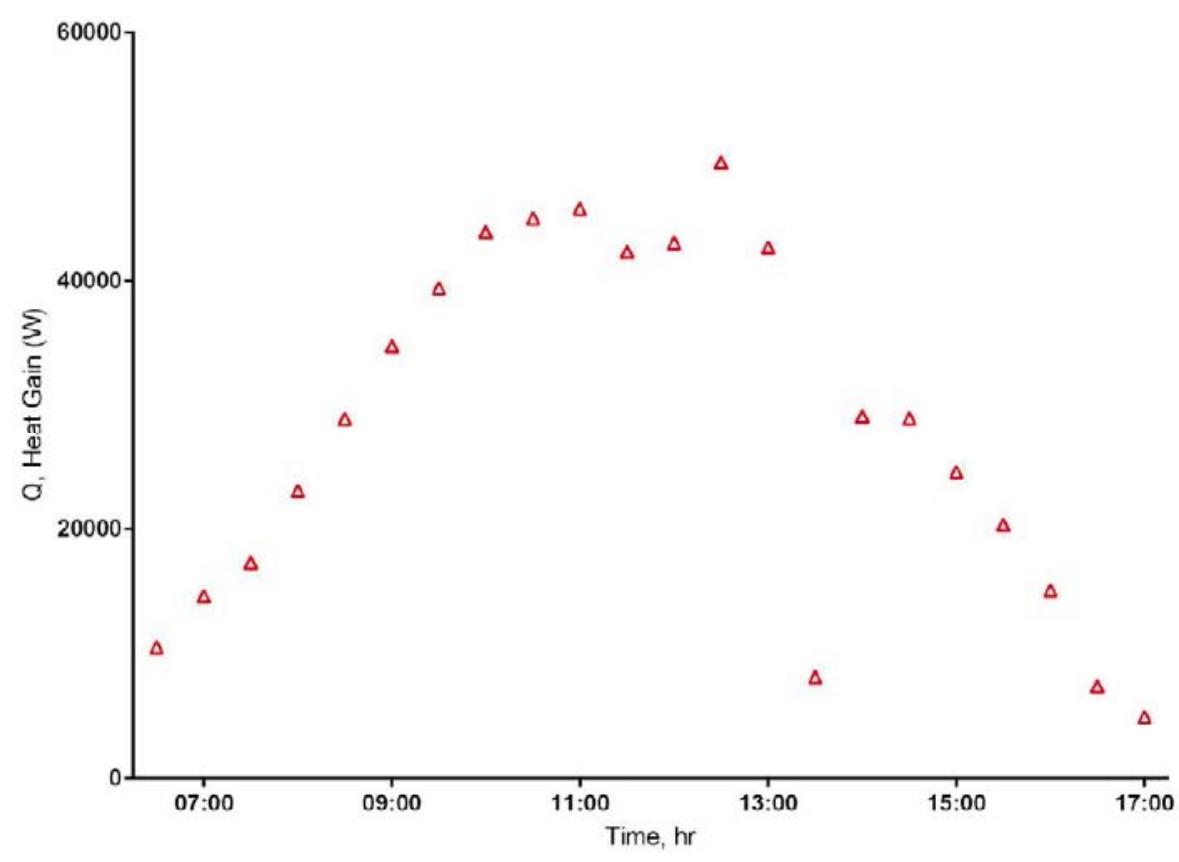

Figure 9: Daily variations in heat gain of air in solar collector. 


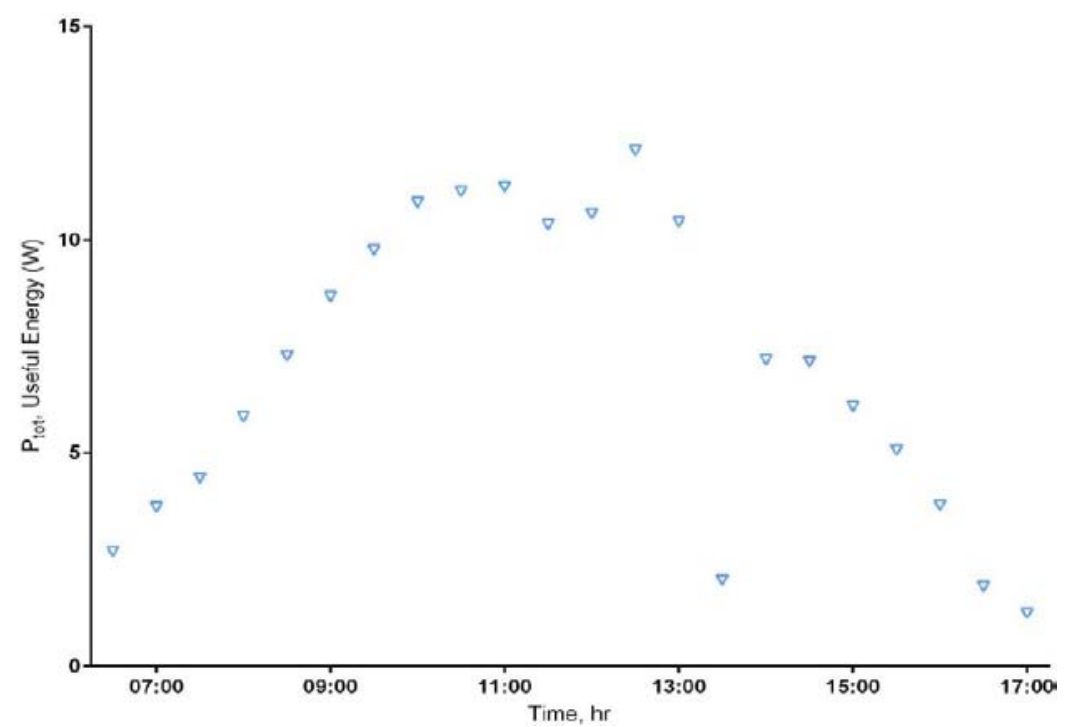

Figure 10: Daily variations in useful energy contained in airflow.

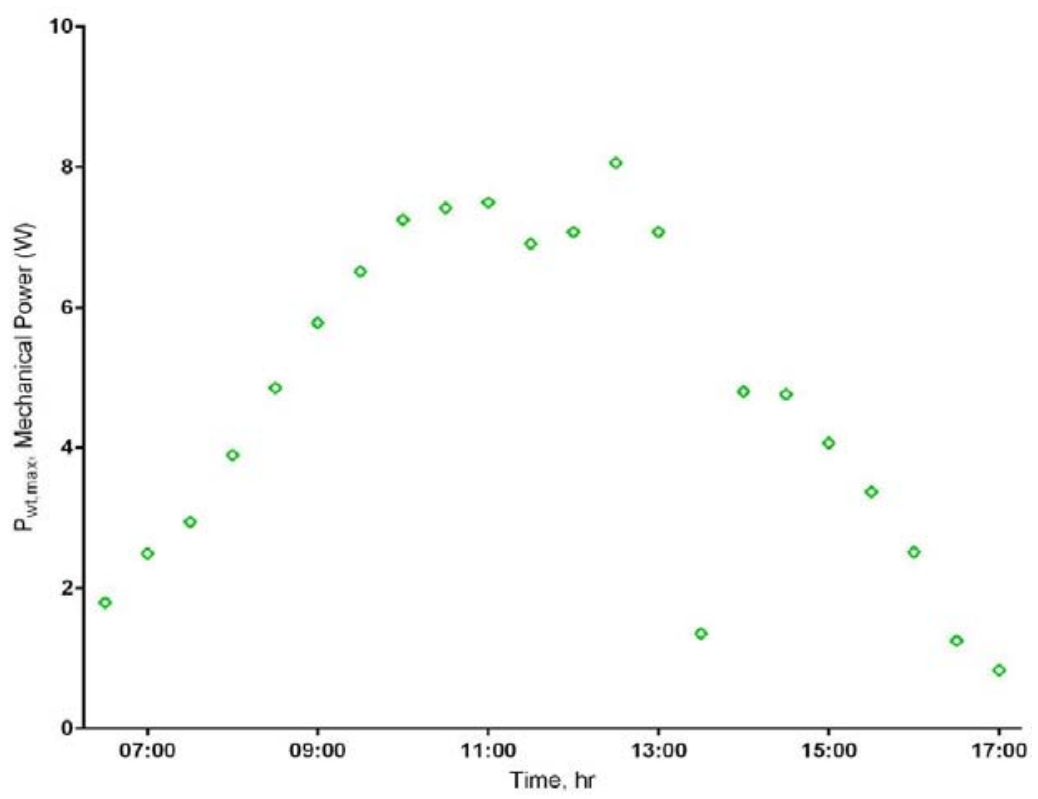

Figure 11: Daily variations in maximum mechanical power taken up by the turbine.

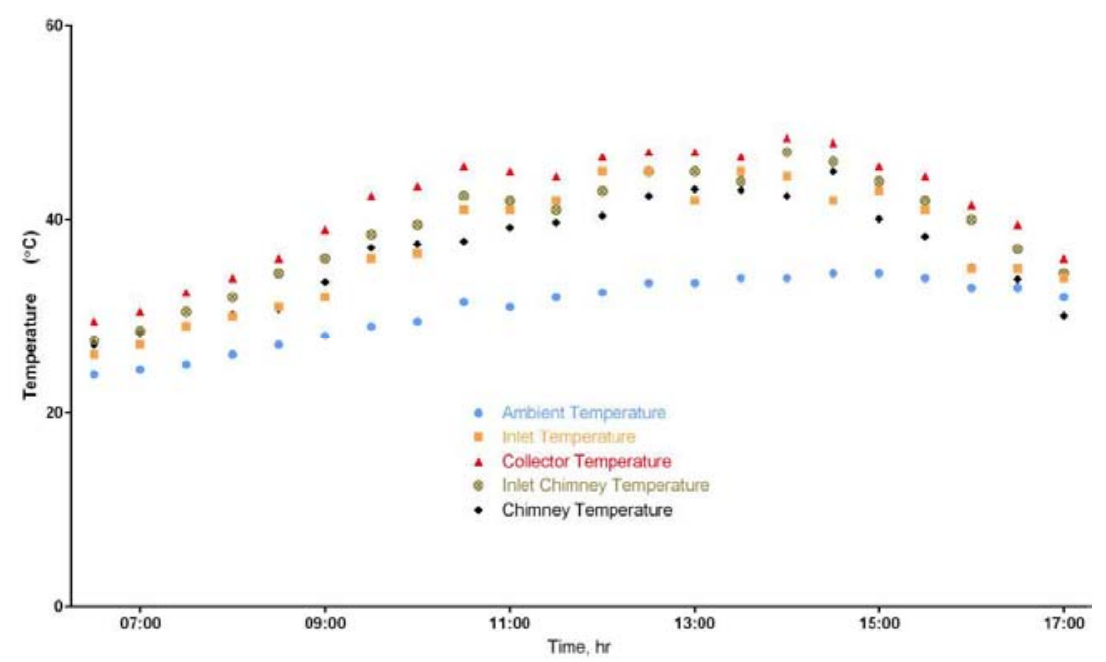

Figure 12: Daily variations in ambient temperature, inlet temperature, collector temperature, inlet chimney temperature and chimney temperature. 


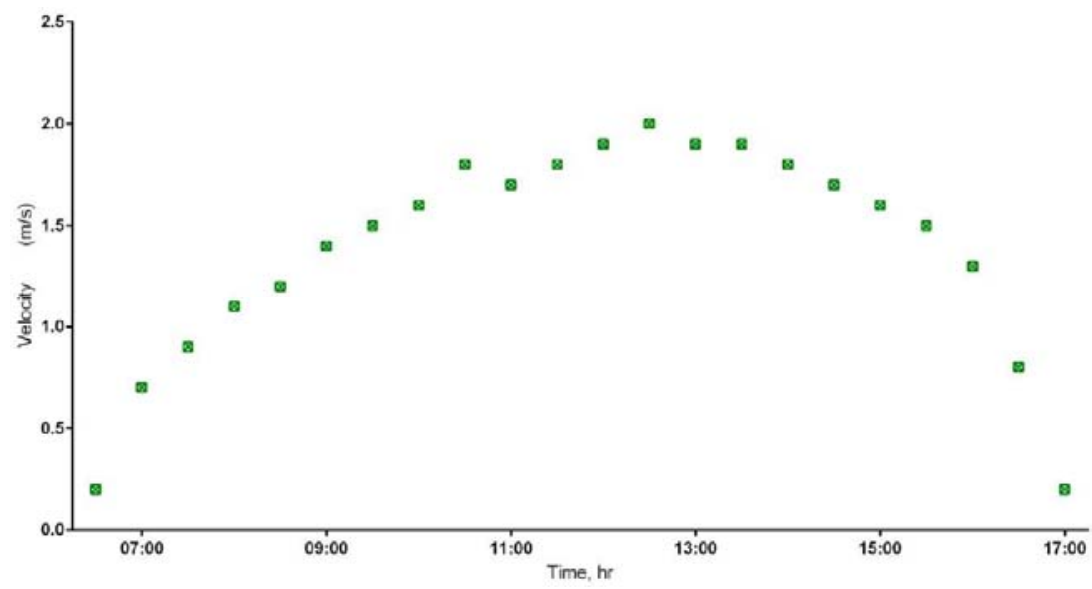

Figure 13: Daily variations in velocity.

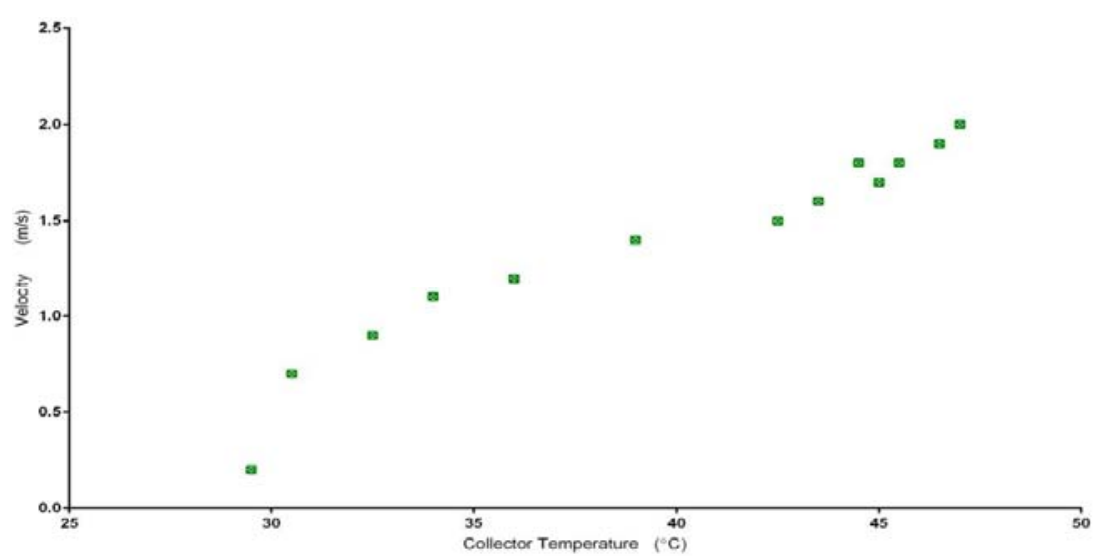

Figure 14: Effect of collector temperature on velocity.

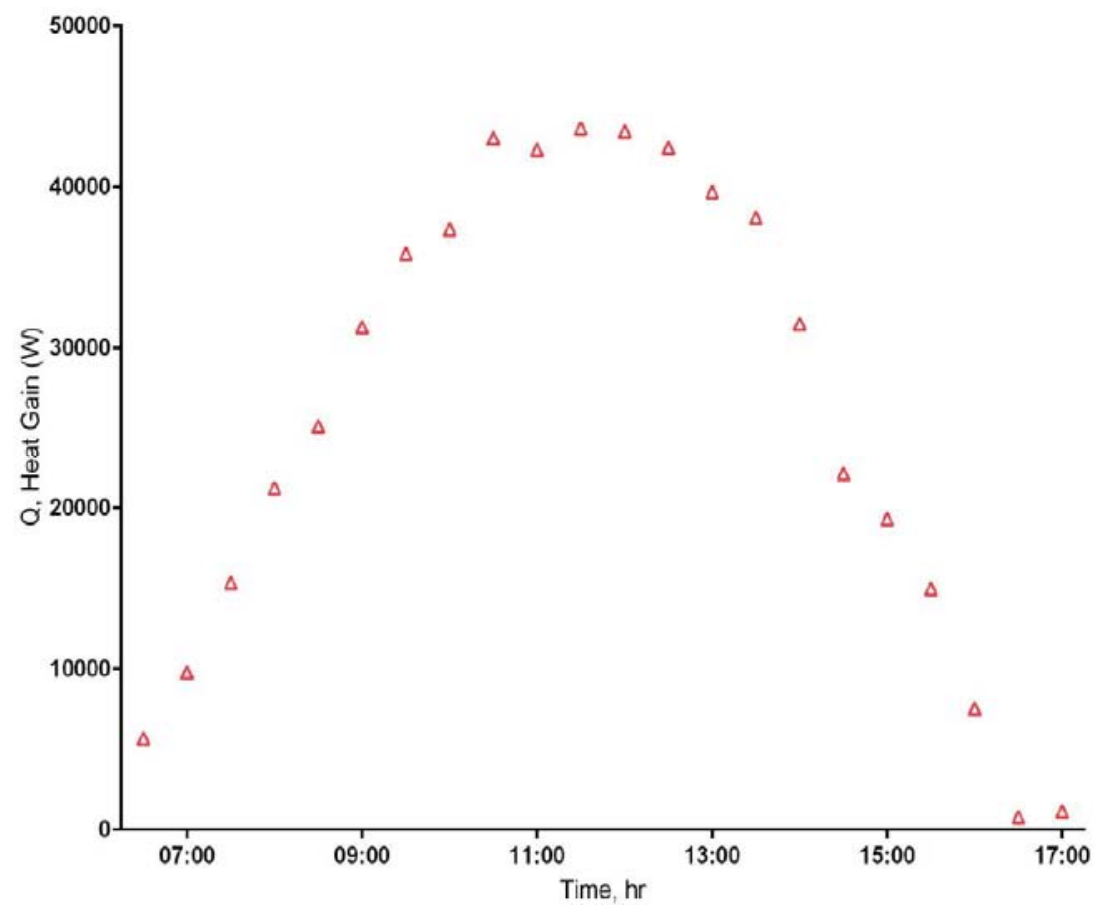

Figure 15: Daily variations in heat gain of air in solar collector. 


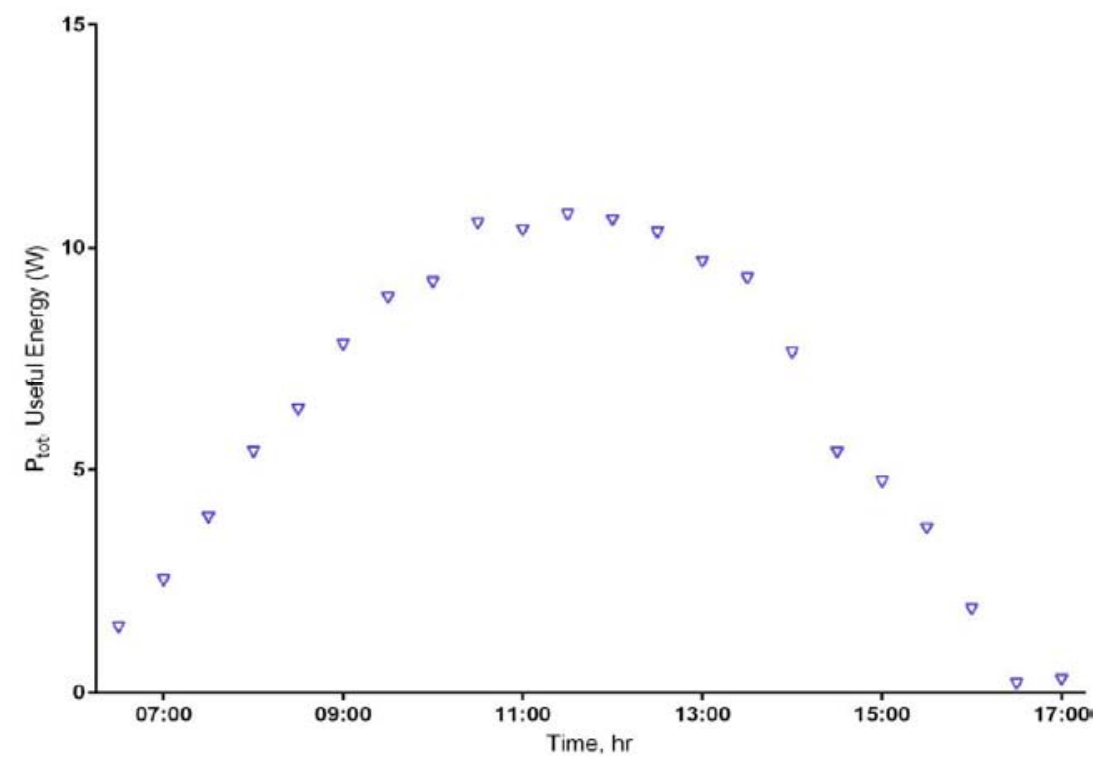

Figure 16: Daily variations of useful energy contained in airflow.

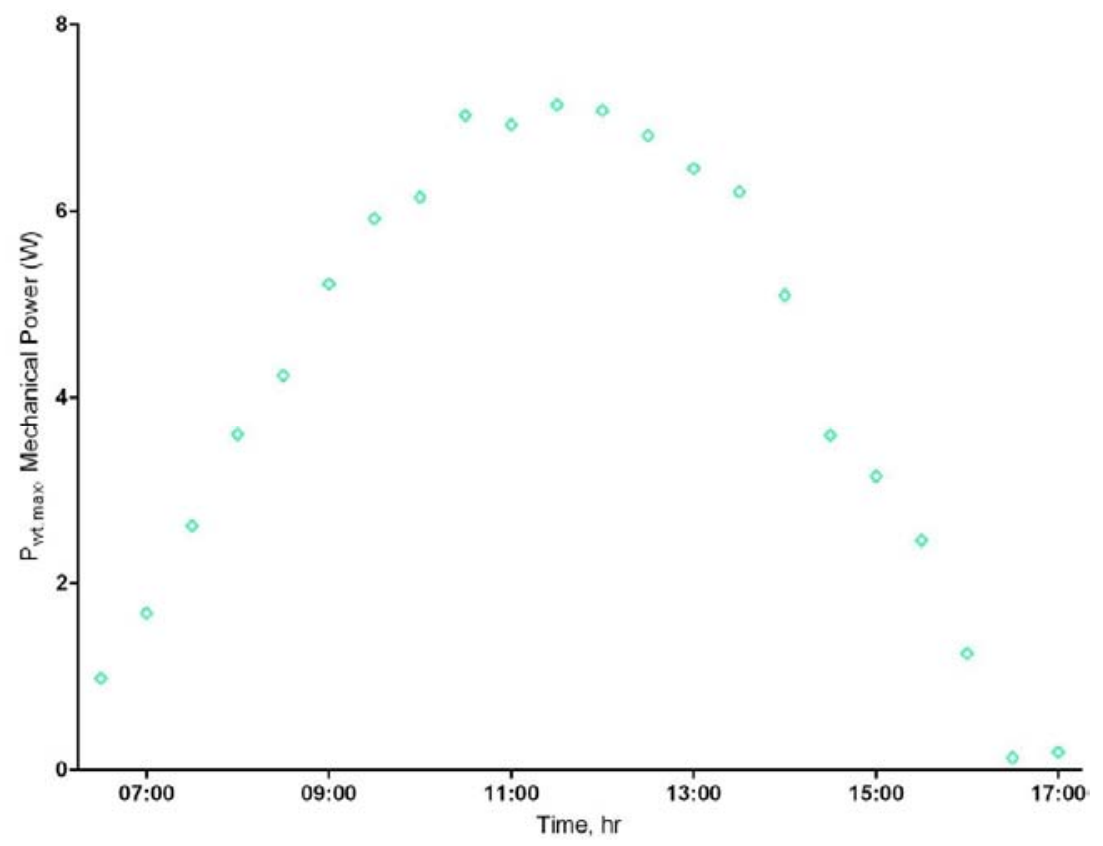

Figure 17: Daily variations of maximum mechanical power taken up by the turbine.

\section{CONLUSIONS}

A solar chimney system was designed and tested under the ambient conditions of Mansoura, Egypt (latitude $31.04 \mathrm{~N}$ and longitude $31.38 \mathrm{E}$ ). The system has a square collector with an area of $100 \mathrm{~m}^{2}$, chimney height of $8 \mathrm{~m}$ and the diameter equals $0.3 \mathrm{~m}$. It's floor was painted with black bitumen and covered with plastic having a thickness of 150 microns. The height of air inlet collector (periphery) was $0.15 \mathrm{~m}$. Tests were carried out at a wide range of ambient temperatures and solar radiation. Experimental measurements indicate that as long as the collector air temperature increases, the velocity of air inside the chimney increases. Maximum mechanical power of about 7 Watt is recorded.

\section{HIGHLIGHTS}

- Performance of a solar chimney is demonstrated.

- Experiments were carried out at different weather conditions.

- The effect of collector temperature on velocity is presented. 


\section{NOMENCLATURE}

$\mathrm{A}_{\mathrm{c}} \quad=$ Cross- section area of the solar chimney $\left(\mathrm{m}^{2}\right)$

$A_{\text {coll }}=$ Solar collector area $\left(\mathrm{m}^{2}\right)$

$\mathrm{C}_{\mathrm{p}} \quad=$ Specific heat of the air $\left(\mathrm{KJ} / \mathrm{Kg}{ }^{\circ} \mathrm{C}\right)$

$\mathrm{g}=$ Acceleration of gravity $\left(\mathrm{m} / \mathrm{s}^{2}\right.$

$\mathrm{G}=$ Solar irradiance $\left(\mathrm{W} / \mathrm{m}^{2}\right)$

$\mathrm{H}_{\mathrm{sc}} \quad=$ Solar chimney height $(\mathrm{m})$

$\dot{\mathrm{m}}=$ Mass flow rate of air $(\mathrm{Kg} / \mathrm{s})$

$P_{\text {tot }} \quad=$ Useful energy contained in airflow (W)

Q = Heat gain of air in the solar collector (W)

$\mathrm{P}_{\mathrm{wt}, \max }=$ Maximum mechanical power taken up by the turbine, (W)

$\mathrm{P}_{\mathrm{e}} \quad=$ Electric output from the solar chimney, (W)

$\mathrm{T}_{0} \quad=$ Ambient temperature $\left({ }^{\circ} \mathrm{C}\right)$

$\mathrm{V}_{\mathrm{c}} \quad=$ Inlet air velocity in the solar chimney $(\mathrm{m} / \mathrm{s})$

$\mathrm{T \alpha}=$ Effective transmittance and absorbance

$\beta=$ Heat loss coefficient $(\mathrm{W} / \mathrm{m} 2 \mathrm{~K})$

$\eta_{\text {coll }}=$ Solar collector efficiency

$\eta_{\mathrm{sc}} \quad=$ Solar chimney efficiency

$\rho \quad=$ Air density $(\mathrm{Kg} / \mathrm{m} 3)$

$\Delta \mathrm{P}_{\text {tot }}=$ Pressure difference produced between the chimney base and surrounding $(\mathrm{Pa})$

$\Delta \mathrm{T} \quad=$ Temperature rise between collector inflow and outflow $\left({ }^{\circ} \mathrm{C}\right)$

$\eta_{\mathrm{wt}} \quad=$ Turbine efficiency

\section{REFERENCES}

[1] Zhou X, Wang F, Ocheing RM. A Review of Solar Chimney Power Technology. Renewable and Sustainable Energy Reviews 2010; 14: 2315-2338.

https://doi.org/10.1016/j.rser.2010.04.018

[2] Badran O, Mamlook R, Hadi EA. Toward Clean Environment: Evaluation of Solar Electric Power Technologies Using Fuzzy Logic. Clean Techn Environ Policy 2012; 14: 357-367. https://doi.org/10.1007/s10098-011-0407-8

[3] Cao F, Li H, Zhamg Y, Zhao L. Numerical Simulation and Comparison of Conventional and Sloped Solar Chimney Power Plants: The Case of Lanzhou. The Scientific World Journal Volume 2013; Article ID 852864, 8 pages. https://doi.org/10.1155/2013/852864
Sun JM, Yang M, Shan YG. The Effect of the Inclined Angel on the Output in a Solar Chimney Power Plant System. International Conference on Power Engineering - 2007, October 23-27, 2007, Hangzhou, China. https://doi.org/10.1007/978-3-540-76694-0 222

[5] Jing W, Fenghao W, Liang Z. Research on the Best Slope Gradient of Slope Solar Induced Convective Flows Power Generation System. Proceedings of ISES Solar World Congress: Solar Energy and Human Settlement 2007.

[6] Schlaich J. The solar chimney: Electricity from the sun, Axel Menges, Geislingen, Germany 1995.

[7] Haaf W, Friedrich K, Mayr G, Schlaich J. Solar chimneys, part : principle and construction of the pilot plant in Manzanares. Int $J$ Solar Energy 1983; 2: 3-20. https://doi.org/10.1080/01425918308909911

[8] Haaf W. Solar chimneys, part II: preliminary test results from the Manzanares pilot plant. Int J Solar Energy 1984; 2: 141-161. https://doi.org/10.1080/01425918408909921

[9] Krisst RJK. Energy Transfer System, Alternative Sources of Energy 1983; 63: 8-11.

[10] Pasurmarthi N, Sherif SA. Performance of a demonstration solar chimney model for power generation, proceeding of the 1997 35th Heat Transfer and Fluid Sacrmento 1997; 203-240.

[11] Dos MA, Bernardes S, Vob A, Weinrebe G. Thermal and technical analyses of solar chimneys. Solar Energy 2003; 75(6): 511-524

https://doi.org/10.1016/j.solener.2003.09.012

[12] Gannon AJ, Backstrom TWV. Solar Chimney Cycle Analysis with System Loss and Solar Collector Performance. Journal of Solar Energy Engineering 2000; 122(3): 133-137. https://doi.org/10.1115/1.1314379

[13] Gannon AJ, Backström TWV. Solar Chimney Turbine Performance. Journal of Solar Energy Engineering 2003; 125(1): 101-106. https://doi.org/10.1115/1.1530195

[14] Schlaich J, Bergermann R, Schiel W, Weinrebe G. Design of Commercial Solar Updraft Tower Systems - Utilization of Sola Induced Convective Flows for Power Generation, Journal of Solar Energy Engineering 2005; 127(1): 117-124. https://doi.org/10.1115/1.1823493

[15] Zhou X, Yang J, Xiao B, Hou G. Experimental study of the temperature field in a solar chimney power setup 2006. https://doi.org/10.1016/i.applthermaleng.2006.12.007

[16] Beerbaum S, Weinrebe G. Solar theramal power generation in India-a techno-economic analysis. Renewable Energy 2000; 21(2): 153-174

https://doi.org/10.1016/S0960-1481(00)00006-9

[17] Solar Tower of Power Finds Home, http://www.wired.com/ news/technology/0,1282,66694,00.html.

[18] Ahmed OK, Ahmed Hassen A. New design of solar chimney (case study). Case Studies in Thermal Engineering 2018; 11 105-112. https://doi.org/10.1016/j.csite.2017.12.008

[19] Dai YJ, Huang HB, Wang NRZ. Case study of solar chimney power plants in North-western regions of China. Renewable Energy 2003; 28: 1295-304 https://doi.org/10.1016/S0960-1481(02)00227-6

[20] Schlaich J. The solar chimney: Electricity from the sun. In Maurer C, editor. Germany: Geislingen 1995.

\section{DOI: https://doi.org/10.15377/2409-5818.2019.06.5}

(c) 2019 Anter et al.; Avanti Publishers.

This is an open access article licensed under the terms of the Creative Commons Attribution Non-Commercial License (http://creativecommons.org/licenses/by-nc/3.0/) which permits unrestricted, non-commercial use, distribution and reproduction in any medium, provided the work is properly cited. 